\title{
The View of Major Religions of India on Brain Stem Death and Organ Donation
}

\author{
Fr. Davis Chiramel ${ }^{1,2}$, V. Sanjeevan Kalavampara ${ }^{3}$, Muhammad Mansur Ali ${ }^{4}$, Bhavneet Singh ${ }^{5}$, Zubair Umer Mohamed ${ }^{6}$ \\ ${ }^{1}$ Infant Jesus Church, Kadangode, ${ }^{2}$ Kidney Federation of India, Thrissur, ${ }^{3}$ Department of Urology, Amrita Institute of Medical Sciences, ${ }^{4}$ School of History, Archaeology \\ and Religion, Cardiff University, Cardiff, UK, ${ }^{5}$ Amritsar Pain, Spine and Arthritis Clinic, Amritsar, Punjab, ${ }^{6}$ Department of Organ Transplant Anaesthesia and Critical \\ Care, Amrita Institute of Medical Sciences and Research Centre, Kochi, Kerala, India
}

\section{Abstract}

Religion plays a major role in the life of most people from the Indian subcontinent. Although religions originated many centuries years ago, the concepts of brain stem death and organ donation are less than a 100 years old. While acknowledging that religions have various denominations and may have varying opinions within them, this article attempts to provide a balanced view of how the major religions in India view these concepts of modern medicine.

Keywords: Brain stem death, Christianity, Hinduism, Islam, Sikhism

Religion plays a major role in the life of most people from the Indian subcontinent. Although religions originated many centuries years ago, the concepts of brain stem death and organ donation are less than a 100 years old. While acknowledging that religions have various denominations and may have varying opinions within them, this article attempts to provide a balanced view of how the major religions in India view these concepts of modern medicine.

\section{CHRISTIANITY}

Fr Davis Chiramel
Vicar- Infant Jesus Church, Kadangode, Kerala and Founder, Kidney Federation
of India

The translations used in this text is from The Holy Bible, New International Version. ${ }^{[1]}$

Christian belief stems from the Bible and the life of Jesus Christ. Christians believe that all humans are bearers of the imago dei (the Latin term for the image of God), which the Creator chose to imprint in humans. Most Christians, conservative and liberal, believe that a person whose brain is dead can no longer

Submitted: 03-May-2020

Published: 18-Aug-2020

\begin{tabular}{|l|l|}
\hline \multicolumn{2}{|c|}{ Access this article online } \\
\hline Quick Response Code: & Website: \\
\hline & www.ajmonline.org.in \\
\cline { 2 - 2 } & \\
\hline
\end{tabular}

express the imago dei, and have therefore, not objected to the current understanding of brain death or brain stem death. For Roman Catholics, the theological implications of death and its signs have been discussed in working groups of the Pontifical Academy of Sciences, the proceedings of which were held in 1985 (the artificial prolongation of life and the determination of the exact moment of death), in 1989 (the determination of brain death and its relationship with human death), and in 2006. These documents acknowledge that brain stem death is equivalent to the commonly understood concept of death. ${ }^{[2]}$ Although the Bible's empirical criteria for recognizing death are the cessation of cardiopulmonary function (Gen 25:8, 35:29; Acts 5:10) accompanied by irreversible loss of consciousness (Psa 6:5; John 11:11, 14), Protestant belief, in general, supports the concept of brain stem death arguing that"mere cellular and organ system activity alone is not sufficient to treat the human body as if it were alive". ${ }^{[3]}$

The medical concept of organ donation is not explicitly mentioned in the Bible. However, parallels can be derived that

Address for correspondence: Dr. Zubair Umer Mohamed, Consultant, Organ Transplant Anaesthesia and Critical Care, Amrita Institute of Medical Sciences and Research Centre, Kochi, Kerala, India. E-mail: zubairumer@gmail.com

This is an open access journal, and articles are distributed under the terms of the Creative Commons Attribution-NonCommercial-ShareAlike 4.0 License, which allows others to remix, tweak, and build upon the work non-commercially, as long as appropriate credit is given and the new creations are licensed under the identical terms.

For reprints contact: reprints@medknow.com

How to cite this article: Chiramel FD, Kalavampara VS, Ali MM, Singh B, Mohamed ZU. The view of major religions of India on brain stem death and organ donation. Amrita J Med 2020;16:82-6. 
Chiramel, et al:: Major religions of India on brain stem death and organ donation

would help to reach conclusions that are in keeping with the biblical teachings. The dominant emphasis in Christianity is the belief in the resurrection of Christ, and many Christians see organ donation as an extention of the teachings and life of Jesus Christ. Verses like Luke 6:38: "Give, and it will be given to you",; Matthew 22:39, Mark 12:31: "Love your neighbor as yourself" are taken as supporting the concept of organ donation which is viewed as a gift of life. Believers of the Christian faith would argue that Jesus has descended to the earth to redeem the humankind by way of donating his blood and body. He proclaims in 1 Corinthians 11:24; "This is my body, which is for you; do this in remembrance of me." His action is seen as an eternal donation. According to biblical sources, it may be viewed as God Himself having performed the first organ transplantation with Adam being the first donor. Genesis 2:20-23 explains that God had taken a bone from Adam's right rib and created Eve-thus completing the first human organ transplantation! Hundreds of volunteers from the parish have made kidney donations, which includes 28 priests, 12 nuns and one Bishop. ${ }^{[4]}$ In fact, Pope Benedict $\mathrm{XVI}$ is registered as an organ donor. Pope Francis' position is that the act of organ donation is a "testimony of love for our neighbor."'[2]

Transplanting organs from a body which is destined to decay, into another live body so as to ensure a new lease of life to the recipient is considered a divine act. Although organ donation is not considered against the overarching Christian spiritual concepts, certain denominations among Christianity, like the Pentecostal Church and Jehovah's Witness, however, have left the decision on accepting brain stem death as equivalent to death, and organ donation to the individual. ${ }^{[5]}$

\section{REFERENCES}

1. The Holy Bible. New International Version. Grand Rapids: Zondervan Publishing House; 1984.

2. Wijdicks EF. Beliefs and brain death. In: Brain Death. $3^{\text {rd }}$ ed. Oxford: Oxford University Press; 2017. P. 98.

3. Available from: https://escholarship.org/content/qt5wg908hk/ qt5wg908hk.pdf. [Last accessed on 2020 Oct 19].

4. Available from: http://epaperbeta.timesofind ia.com/Article.aspx?eid=31811 and articlexml=A-selfless-act-that-set-live-donor-trend-11082016002024. [Last accessed on 2020 Oct 19].

5. Available from: http://www.donorrecovery.org/learn/religion-andorgan-donation/. [Last accessed on 2020 Oct 19].

\section{HINDUISM}

\section{Dr. V. Sanjeevan Kalavampara \\ Professor of Urology, Amrita Institute of Medical Sciences, Kochi, Kerala, India}

According to Hindu theology, although physical body and the soul are considered separate, with the association present only during life, the seat of the soul (Ātmā or jiva) is a matter of debate. Ātmā is repeatedly commented upon by the Upaniṣads (Praśna Upaniṣad 3.6, Chāndogya Upanișad 3.14.3 and 8.3.3, Kaṭha Upaniṣad 2.20, Muṇụaka Upaniṣad
3.1.7, Śvetāśvatara Upanișad 3.11, 3.13 and 4.17) and also by Bhagvad Gīta (verses 13.17, 15.15 and 18.61). ${ }^{[1]}$

The Bhagavad Gīta is understood to have alluded to the supersoul (paramatma) being located in the heart (Bhagvad Gita 18.61) and jiva (soul) attached to the physical body till the heart stops. Medical texts such as Charaka Samhita and Sushruta Samhita says the blood cells take the life energy from the heart to the entire body. An alternative interpretation of the "seat of the soul" is that, the "heart" mentioned is not the physical heart but means "central" or "cardinal." Praśna Upaniṣad 3.6, Chāndogya Upanișad 8.6.6 and Kaṭha Upanișad 6.16 mentions about 101 nerves arising from the Heart, branching into 100 branches each, all of them branching further into 72,000 each, making it into 727.2 million nerves emanating from the Heart. ${ }^{[1]}$ Whether the number is true or not, such branching off of nerves occurs from parts of brain. The location of this Heart of consciousness or perhaps the Thalamus is such that it is in line with the middle point between eye-brows (भ्रूम्य - bhrūmadhya) and also with the upper-most point of the nose (नासकिग्र - nāsikāgra). The common point of bhrūmadhya and nāsikāgra is where one is required to concentrate his or her attention during meditation. This would mean that the center of the light or consciousness is in this region-the location of the mythological "Third Eye," the eye of self-realization or enlightenment. The disconnection of this Ātmā from the Heart of Consciousness (brain) can thus be logically interpreted as death.

Jiva (soul) is considered the owner of one's physical body. In Hindu Sastras, jiva is fully authorized to donate one's own body as a whole or in part. Bhagavad Gita says that individual soul is separate from the body. The soul is described to be unbreakable, insoluble, which cannot be burned or dried, unchangeable, invisible, all-pervading, and eternal while the body is perishable. Knowing this, one should not grieve for the body (Bhagvad Gita 2:22, 24, 25). There is no evidence of objections in Hindu scriptures to organ donation while alive or after cessation of life. Some views seem to support the concept of donation as a praiseworthy deed when done as a selfless act for the welfare of humanity. Maharshi Dadhichi who is remembered as the destroyer of many superstitions and believed to have taught men how to kindle fire is described in Vedas (Rigveda hymns 1.80.16, 1.84.13-14, 1.116.12, 1.117.22, 1.139.9, 9.108.4) and Mahabharata, Srimad Bhagawatam and Srimad Devi Bhagawatam ${ }^{[2]}$ as having sacrificed his life to confer his bones to Indra to make the legendary indestructible and irresistible weapon Vajra (diamond or thunderbolt) on the advice of Lord Vishnu to destroy the demon Vritra. The government of India released postal stamp in the name of Marshi Dadhichi to commemorate his great tyaag (sacrifice) and selflessness [Figure 1]. In one of the stories from Mahabharata, King Shibi is said to have "donated" his body piece by piece to feed the hungry eagle in order to save a pigeon, which was the intended prey (food) 
Chiramel, et al.: Major religions of India on brain stem death and organ donation

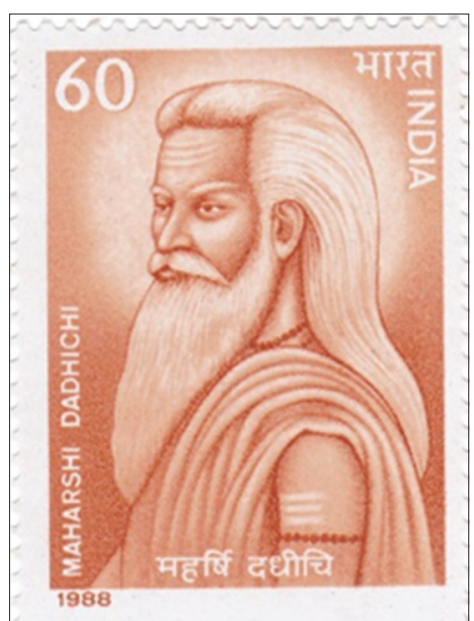

Figure 1: Postal stamp in commemoration of Maharshi Dadhichi

for the eagle. As the savior of all livings beings of his country called Ushinara, King Shibi had assured to protect the pigeon when it took shelter in the King who was not aware that it was being chased by the eagle (Mahabharata: Aranya parva, Adhyayas 130-131; Ramayana: Ayodhya Kanda, Sarga 58). One temple in Andhra Pradesh, Sri Kalahasti, is popular in the name of a hunter named Kannappa Nayanar who plucked his own eyes, one after the other, while alive and offered to his Lord Shiva when he saw blood and tears oozing from his Lord's eyes. ${ }^{[3]}$ Kannappa thought that his Lord's eyes were injured, and it was more important for his Lord to have good eyes than for himself.

The final disposition of one's body after cessation of life is usually by donating it to fire by way of cremation and in certain sects, children and sanyasis, by burial directly in the soil. Other regional differences include offering the body to the river or ocean. Unless it is a public crematorium, the land where cremation or burial is done is usually taken back for ordinary use like cultivation without reserving the area to erect any memorial. Hinduism is an open religion and the opinions of several seekers and seers are accepted as their way of life to follow. There is no compulsion to follow a single path, and hence, it seems to be a personal decision regarding the body and organ donation. Organ or whole body donation for the welfare of others or the society, while alive or after death, is considered as a great service in Hinduism.

\section{ReFEREnCES}

1. Sreedharan K. The Science of Prashna Upanishad. Bhaktivedanta Ashram; 2017. Available from: https://www.indiadivine.org/scie nce-prashna-upanishad/. [Last updated on 2017 Jul 11; Last accessed on 2019 Oct 30].

2. Amritapuri Archives. Dadhichi Saves the Gods in Ahmadabad 2000. Available from: https://www.amritapuri.org/3617/dadhichi-saves. aum. [Last updated on 2000 Feb 180; Last accessed on 2019 Oct 30].

3. Girish Chandra S. Srikalahasti: Interesting Things about Temple. Available from: https://srikalahastiswaraswamy.webs. [Last accessed on 2019 Oct 30].
ISLAM

\section{Dr. Muhammad Mansur Ali}

Lecturer in Islamic Studies, Centre for the Study of Islam in the UK, School of History, Archaeology and Religion, John Percival Building, Cardiff University, UK

\section{Death In IsLam}

Death in Islam is understood as the exiting of the soul from the human body ${ }^{[1]}$. The Quran describes this phenomenon in the following verse, "He is the Supreme Master over his subjects. He sends out recorders to watch over you until, when death overtakes any of you, those sent by us take his soul - they never fail in their duty (Qur'an, 6:61)."

The Prophet Muhammad is documented to have said that when the soul leaves the body, the eyes follow the soul. ${ }^{[2]}$ Death from this point of view is a metaphysical phenomenon which cannot be empirically verified. Beyond this terse description, there is nothing more substantial in Muslim scriptures related to the onset of death or the signs of death. Muslim scholars are left to work out the particulars of this based upon their interpretations of source texts, their own experiences and the knowledge of medicine at the time.

Scholars in the past have debated whether death is an entity or a nonentity. In other words, is death the absence of life or a separate entity closely related to life, but independent of it. Both opinions have been put forward. ${ }^{[3]}$ The ramification of this difference is thrown into relief in the case of death determined by neurological criteria. If death is the departure of the soul from the body and it is the absence of life, any biological functioning of the body, albeit mechanically and irrespective of how diminished the quality of life is, is evidence of the presence of the soul in the body. Thence, retrieving organs from a brain stem patient will be akin to murdering a dying but still living person. On the contrary, if death is an independent entity, it is incorrect to bracket the presence of the soul with some biological features of the body. According to this understanding of life and death, retrieval of organs in the case of brain stem death is not problematic even though some mechanically supported biological functions remain. There are precedents in Islamic law manuals for similar types of deaths where a person has somatic activity but yet declared to be legally dead (al-hayy fi hukm al-mayyit). ${ }^{[4]}$ Furthermore, they have listed a number of signs which signals the onset of death. These include: limpness of the spine and limbs, change of color, glaring of the eyes, depression of temples, slanting of lips, opening of the lips, ascending of the testicles with the drooping of the scrotal skin. With the exception of the eyes, none of the other signs have been mentioned in the scriptural sources. Interestingly, cessation of the heart does not fare in this list. When in doubt, Muslim scholars have opted for putrefaction, to leave the body alone until the stench of rotting flesh can be smelt. ${ }^{[5]}$ Such was their caution in establishing irreversibility that they were ready to tolerate this infraction on the dignity of the deceased. 


\section{Islamic Opinions on Brain Stem Dead Organ DONATION}

In the absence of any clear indications from Muslim scripture, scholars have discussed the issue from the 1920s. ${ }^{[6]}$ A number of conferences held worldwide since the 1980s discussed this issue. The Indian Fiqh Academy in its second seminar in 1989, declared that organ donation is only possible from a live donor. For them, cadaver donation is mutilation and an affront to the sanctity of the body. It unnecessarily prolongs the burial and views the deceased as a repository of organs, to be procured and discarded. The conference of Islamic Fiqh Academy in 1985 declared both live and cadaver donation to be permissible. Furthermore, it declared that in the case of cadaver donation the following conditions need to be fulfilled: (a) the deceased was legally competent when alive (b) and proper consent was given. ${ }^{[7]}$ This conference did not discuss the issue of brain stem death and seemingly gave the impression that all forms of cadaver organ donation is permissible. However, a separate conference held in 1988 discussing the removal of artificial ventilation declared that in the case of brain stem death, it is permissible for doctors to switch off the machine; however, the person will not be declared "Islamically dead" until complete cessation of heartbeat and breathing has not taken place. This latter decision, although not directly related to the organ retrieval process, has to be read in tandem with the former cadaver organ donation position.

A different Islamic research organization known as International Islamic Fiqh Academy (IIFA) in 1986 declared death determined by neurological criteria as genuine Islamic death. Although there are now two conflicting opinions on the issue of brain stem death and organ retrieval, the Saudi government adopted the position of the IIFA ${ }^{[8]}$ as a result of which organ transplantation programs were given the green light in the Kingdom. ${ }^{[9]}$

Dr. Rafaqat Rashid, a Muslim scholar and medical doctor from the UK, moves the debate to a slightly earlier time. He argues that death is the "permanent loss of capacity of higher brain functioning ... the rational soul has permanently lost its capacity of control of the critical human and rational components of the body." ${ }^{[10]}$ However, Rashid argues that since there is no universal accurate anatomical criterion for a higher brain formulation of death, the brain stem death criteria should be the closest and most accurate one to employ.

\section{CONCLUSION}

The concept of brain stem death creates a peculiar situation - a betwixt and between position - where the patient is dead from one perspective and yet has signs of the living from another such as warmth, heartbeat, and "breathing."[11] Some argue that the prognosis of death has been confused with its diagnosis; and the death of the organism is being conflated with the death of an organ. An exploration of the constituent members of the three Islamic Fiqh Organizations revealed that two out of the three (Indian IFA and Makkah IFA), constituted wholly of Muslim scholars. The IIFA (which declared brain stem death as Islamic death) is made up of Muslim scholars as well as Muslim medical professionals. The differences in the educational makeup of the membership of the three organizations are telling of their ontological understanding vis-à-vis the human, life, and death.

The current Islamic view of the issue of brain stem organ retrieval is a deadlock situation borne out of competing worldviews and ontological understandings of what a human being is. One either has to accept that a semblance of biological life is an indicator of the presence of the soul or not, accept the existence of a competing view and move on.

\section{REFERENCES}

1. Butt MZ. Organ Donation and Transplantation in Islam: An Opinion; 2019. Available from: https://nhsbtdbe.blob.core.windows.net/ umbraco-assets-corp/16300/organ-donation-fatwa.pdf. [Last accessed on 2020 Apr 29].

2. Al-Baqi MF, editor. Muslim ibn Al-Hajjaj. Sahih Muslim. Beirut: Dar al-Ihya al-Turath al-Arabi; 1976.

3. Ayni Ba-D. Al-Binaya Sharh al-Hidaya. Beirut: Dar al-Kutub al-Ilmiyya; 2000.

4. Tahtawi AM. Hashiya al-Tahtawi ala Maraqi al-Falah Sharh Nur al-Idah. Beirut: Dar al-Kutub al-Ilmiyya 1997.

5. Ibn Abidin M. Radd al-Muhtar Hashiya Durr al-Mukhtar. Beirut: Dar al-Fikr; 1992.

6. Sa'di A. Hukm Naql al-A'da. In: Al-Sa'di MbA, editor. Majmu' al-Fawa'id wa Iqtinas al-Awabid in Majmu' Mu'allafat al-Shaykh AbdurRahman b Nasir al-Sa'di. 21. Qatar: Wazarat al-Awqaf wa al-Shu'un al-Islamiyya; 2011. p. 95-100.

7. IFA. Declaration of the Islamic Fiqh Academy in its $8^{\text {th }}$ Session (1985). Majallat al-Majma'at al-Fiqhi al-Islami 1985;1:77-80.

8. IIFA. Resolution on organ donation of the international Islamic Fiqh Academy in its $4^{\text {th }}$ session. Majallat al-Majma' al-Fiqh al-Islami al-Duwali 1988;4:507-10.

9. Albar MA. Al-Mawqif al-Fiqhi wa al-Akhlaqi min Qadiyat Zar' al-A'da'. Damascus: Dar al-Qalam; 1994.

10. Rashid R. In: Organ Transplantation- An Islamic Perspective to Human bodily Dignity and Property in the Body. Al Balagh Academy. Bradford, England. 2018.

11. Hamdy S. Not quite dead: Why Egyptian doctors refuse the diagnosis of death by neurological criteria. Theor Med Bioethics 2013;34:147-60.

\section{SIKHISM}

\section{Dr. Bhavneet Singh}

Director, Amritsar Pain, Spine and Arthritis Clinic, Amritsar, Punjab, India

Sikhism is a monotheistic religion founded in $15^{\text {th }}$ century by Guru Nanak Dev (1469-1538). The word "Sikh" means learner, and there are no ordained priests in Sikhism; the Sikh temple (gurdwara) is in the core of the reader (granthi), who is appointed by the community. Sikh philosophy and teachings place great emphasis on the importance of giving and putting others before oneself. Sikhism also stresses the importance of doing good actions. Guru Granth Sahib, the Sikh holy scripture, states:

"Where self exists, there is no God; Where God exists, there is no self" ${ }^{\prime[1]}$ 
Guru Nanak, (founder of Sikh faith and first of the ten gurus)

Sikhs generally accept brain stem death as an indication of the departure of life from a body. ${ }^{[2]}$ Seva (the act of selfless service, to give without seeking reward or recognition) is at the core of being a Sikh. Seva can also be about donating your organ to another. Saving a human life is one of the greatest things one can do according to the Sikh religion, and for this reason, donating organs after death is acceptable to Sikhs. By organ donation, we provide the greatest "seva"-giving life to others by donating our organs to those in need. One important factor to bear in mind is that, after death, not remove any of the five K's-Kesh (uncut hair), Kara (a steel bracelet), Kanga (a wooden comb), Kaccha-(cotton underwear), Kirpan (steel sword) if the person is wearing them, without discussion with family.

The Guru Granth Sahib is replete with advice regarding the approach to death.

"whosoever is born, he must perish today or tomorrow."

Guru Teg Bahadur (Guru Granth Sahib, p-1429)

"The dead sustain their bond with the living through virtuous deeds."

Guru Nanak (Guru Granth Sahib, p-143)

When the soul departs from the body, the body is useless.

(Guru Granth Sahib, Holy scripture).

"If a corpse is anointed with sandalwood oil, what good it does? If a corpse is rolled in manure, what does it lose from this?" (Guru Granth Sahib).

According to Sikh religion, the soul migrates in the perpetual cycle of rebirth, but the physical body is only a vassal in its long journey, left behind each time and dissolved into the elements, as the Guru Granth Sahib says in Asaa Mahal 5 "That time, which the mortal does not wish for, eventually comes without the eternal order the understanding of mortals is never understood. The body is consumed by water, fire, and earth. But the soul is neither young nor old. Humans, thus, it is the soul and not the body which continues its journey."

Lord Singh of Wimbledon CBE, Director of the network of Sikh Organizations, UK, states, 'The Sikh religion teaches that life continues after death in the soul and not the physical body. The last act of giving and helping others through organ donation is both consistent with and in the spirit of Sikh teachings.' Dr. Jasdev Rai, British Sikh Consultative Forum, adds, 'And why not donate an organ so another can live?'

The Gurdwara Counsel encourages people of Sikh faith to register to be organ donors. ${ }^{[2]}$

\section{Acknowledgement}

Fr. Chiramel's audio inputs were translated and transcribed by Ms Divya G, Staff Nurse, Charing Cross Hospital, London, UK, and Dr. Zubair Umer Mohamed. The final manuscript was approved by Fr. Chiramel).

\section{Financial support and sponsorship}

Nil.

\section{Conflicts of interest}

There are no conflicts of interest.

\section{REFERENCES}

1. Khalsa.Sant Singh. In: Siri Guru Granth Sahib(English Translation of Siri Guru Granth Sahib). Tuscon,AZ, USA:Hand Made Books.

2. Available from: http://www.gosh.nhs.uk. [Last accessed on 2019 Oct 24]. 